\title{
Comparative method with the use of laser scanning as a starting point for the assessment of the state of preservation of the face of the walls in the Kłodzko Fortress
}

\author{
Piotr Gleń \\ https://orcid.org/0000-0002-2975-408X \\ p.glen@pollub.pl
}

\section{Karol Krupa \\ https://orcid.org/0000-0002-7373-4080 \\ k.krupa@pollub.pl}

Faculty of Civil Engineering and Architecture, Lublin University of Technology

\begin{abstract}
This article presents architectural studies of the state of preservation of the face of the wall of the Kłodzko Fortress on the basis of the surveying works performed since 2016. These works include measurement of the entire fortress with the use of laser scanning. The analysis was carried out on the face of the wall, gradually degrading due to external factors and incorrect protection of the masonry. For detailed analysis, clouds of points from the period of 2 years (2017-2018) were used, taking into account the discussed northern part of the wall of the Great Tenaille (Wielkie Kleszcze). The paper explains the importance of the surveying process for the conservation works aiming at protection of the historical tissue from further degradation.
\end{abstract}

Keywords: fortress, Kłodzko, survey, fortification, 3D scanning, cloud of points

\section{Introduction}

The aim of the studies conducted by the research team from the Lublin University of Technology is a detailed survey of the fortification complex of the Kłodzko Fortress with the use of laser scanning (Fig.1). With this measurement technology, a database of spatial information in the form of a cloud of points is obtained [1]. Laser scanning allows to obtain spatial data regarding existing structures. The use of scanners in surveying works has many advantages, making them more and more commonly used worldwide [2]. Due to this, the subsequent processing of the measurement material becomes possible in most of the programs used for creating survey documentation in the 2D form. It is an important starting point for further conservation activities concerning the protection of historic monuments. The acquired database enables a detailed assessment of the technical condition of the analysed structure. An important argument in favour of using laser scanning technology in conservation works is a very precise presentation of the existing state of a building with maximum measurement accuracy. Collected measurement data in the form of a cloud of points can be used in many ways, from a 2D survey to the formation of three-dimensional reconstructions or analyses of degradation of the elements of a facility. The authors of the paper focus on a comparative analysis of performed scans of a part of the wall of the Kłodzko Fortress, which underwent significant degradation. The documentation resulting from the annual research works carried out at the Kłodzko Fortress allows to analyse the progress of degradation of the 
face of the wall caused by external factors such as invasive greenery, weather conditions or inadequate protection of endangered elements.

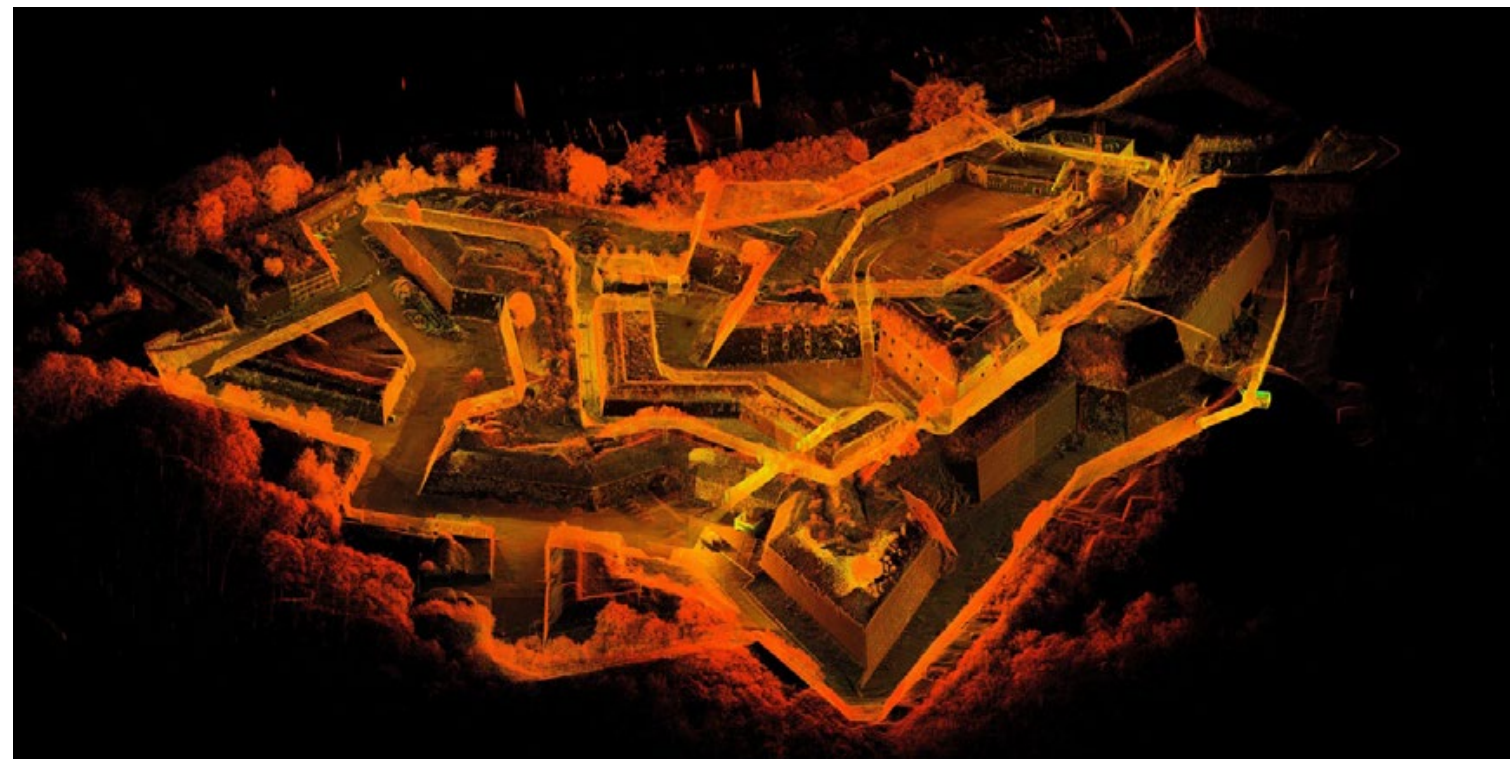

Fig. 1. Scan of the Kłodzko Fortress generated with the use of Leica Cyclone program - authors' own elaboration

The authors of the article present, on the example of the Kłodzko Fortress, the dangers associated with brick slopes and building facades. The proposed protective measures are aimed at stopping further degradation of the discussed part of the wall.

\section{The Kłodzko Fortress}

The town of Kłodzko is situated in the Lower Silesian Voivodship, in the Kłodzko Poviat. The Kłodzko Fortress was founded in the $17^{\text {th }}$ century. The state of preservation of this fortress as a whole fortification complex gives it a unique character in Poland [3]. The fortress itself was built on the site of a medieval castle erected in the $14^{\text {th }}$ century. During the Second World War the SS headquarters were located there [4]. After the war, it was the site of the AEG armaments factory and then, it became the property of the army that was stationed in the fortress [5]. In 1960, the facility was entered in the Register of Historic Monuments [6]. At present, it is partly available for tourist and museum purposes.

Following the example of the Srebrna Góra Fortress, in 2005 the City of Kłodzko passed a resolution on the creation of the Kłodzko Fortress Cultural Park [7]. It is one of the best preserved fortifications in Poland. That is why the authors of the article draw particular attention to the aspect of protection of the historic fortress by proper conservation activities. A detailed survey of the fortress is the starting factor for this research.

\section{Comparative analysis with the method of laser scanning}

The basic material needed during the conservation works is to carry out a detailed survey of a historic building. The survey of historic buildings should be carried out meticulously, taking into account all the architectural details and available historical information indispensable to analyse the historical tissue. Terrestrial laser scanning allows the implementation of complex studies and analyses, which have not been available so far for any of the measurement techniques [8]. Thanks to the detailed survey note, a comprehensive analysis of a degraded tissue is possible that is necessary for further conservation works related to the protection of a historic monument. In the analysis of the face of the wall, laser scanning technology was used in order to assess the technical 
condition as accurately as possible. The scan of the building was made with the Leica C10 device. This measurement allows to obtain very accurate data including dimensions, geometry and structure of a measured site [9]. This is the best surveying method used for historic buildings [10]. The studied part of the wall is located in the northern part of the Kłodzko Fortress (Fig. 2).

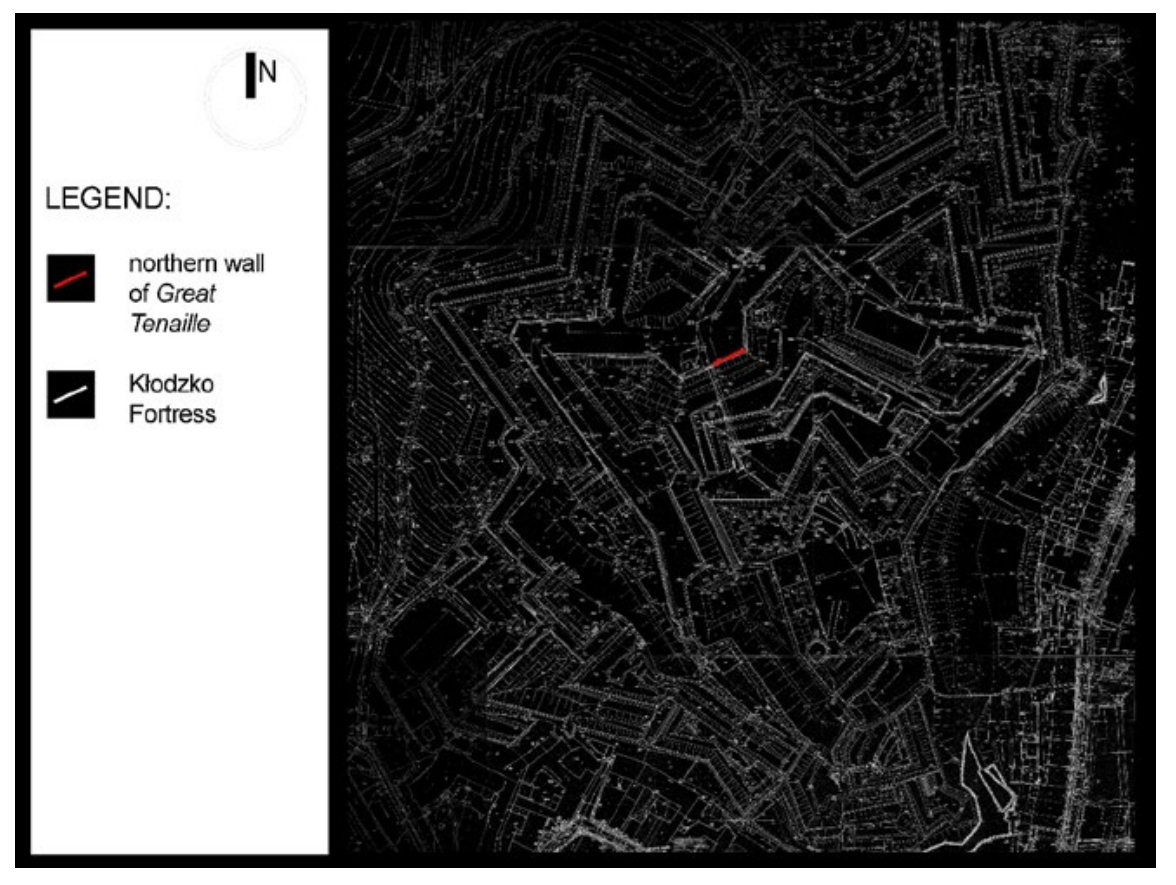

Fig. 2. Overview map with the location of developed part of the wall - authors own elaboration

Laser scanning is currently one of the most accurate measurement techniques used in works related to the survey of historic buildings [11]. Research carried out on the facility since 2016 enables, among other things, gradual conservation works related to the assessment of the technical condition of selected elements showing signs of progressive degradation. This is important during the evaluation of conservation works and preparation of a cost estimate for the repair of degraded elements. The measurements carried out annually by the research team from the Lublin University of Technology allow comparative analysis of selected parts of the fortress walls. By analysing the survey material, it is possible to assess the level of damage and growth of invasive greenery over the years in which the measurement was carried out.

\section{Hazards and recommendations related to masonry slopes and building facades}

The façade of the Great Tenaille (Wielkie Kleszcze), subjected to comparative analysis, located in the northern part of the Kłodzko Fortress, was surveyed with the use of a laser scanner. The scanning includes annual measurements from 2016. Measurements from 2017 and 2018, during which the face of the wall significantly subsided, were analysed. The authors of this study draw attention to the critical condition of the wall: in the central part of the façade, a significant sliding of the face of the wall was visible (Fig. 3). Point but deep rock losses have been observed. A significant part of the façade was overgrown with invasive greenery: grass, moss, and bushes. On the $1 / 4$ of the façade, the face of the wall was visibly bulging. There was noticeable lack of cornice on the length of $7.5 \mathrm{~m}$, and the condition of the cornices was alarming. The face of the wall is assessed as being in bad technical condition, i.e. the structure was in critical condition, with the urgent need for reinforcement, renovation or replacement; it constitutes a direct threat to the health and life of people in the building or its vicinity. Immediate intervention is required regarding safety works based on conservation guidelines. The reason for the collapse of the face of the wall was probably poor protection of the defect that had occurred 
earlier. The authors conclude that the reinforcement in the form of a concrete layer (Fig. 4) was not properly anchored to the original brickwork layer, which resulted in further corrosion of the brickwork material and, as a consequence, the significant part of the brickwork slipped. After comparing the measurement carried out in 2017 (Fig. 5.) with the measurement carried out in 2018 (Fig. 6.), a secondary reinforcement is visible in the place of the loss in the masonry, which resulted in separation from the original masonry material and, as a result, sliding of both the supplementary material and the further part of the original masonry element. After generating a cloud of points from the Leica Cyclone program showing a horizontal cross-section at the point where the layer of masonry slipped, the depth of the cavity was determined to be up to $0.5 \mathrm{~m}$ (Fig. 7).

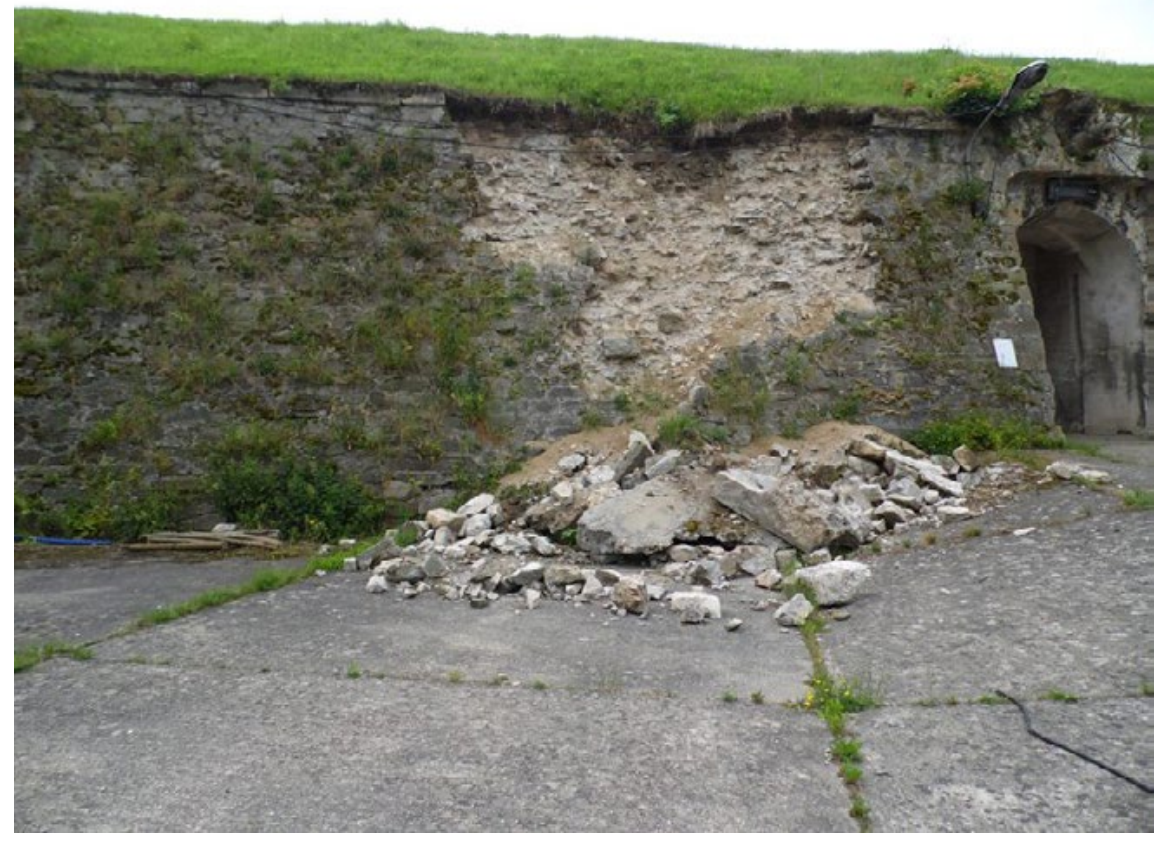

Fig. 3. Photograph showing the wall face (2018) - authors' own photograph

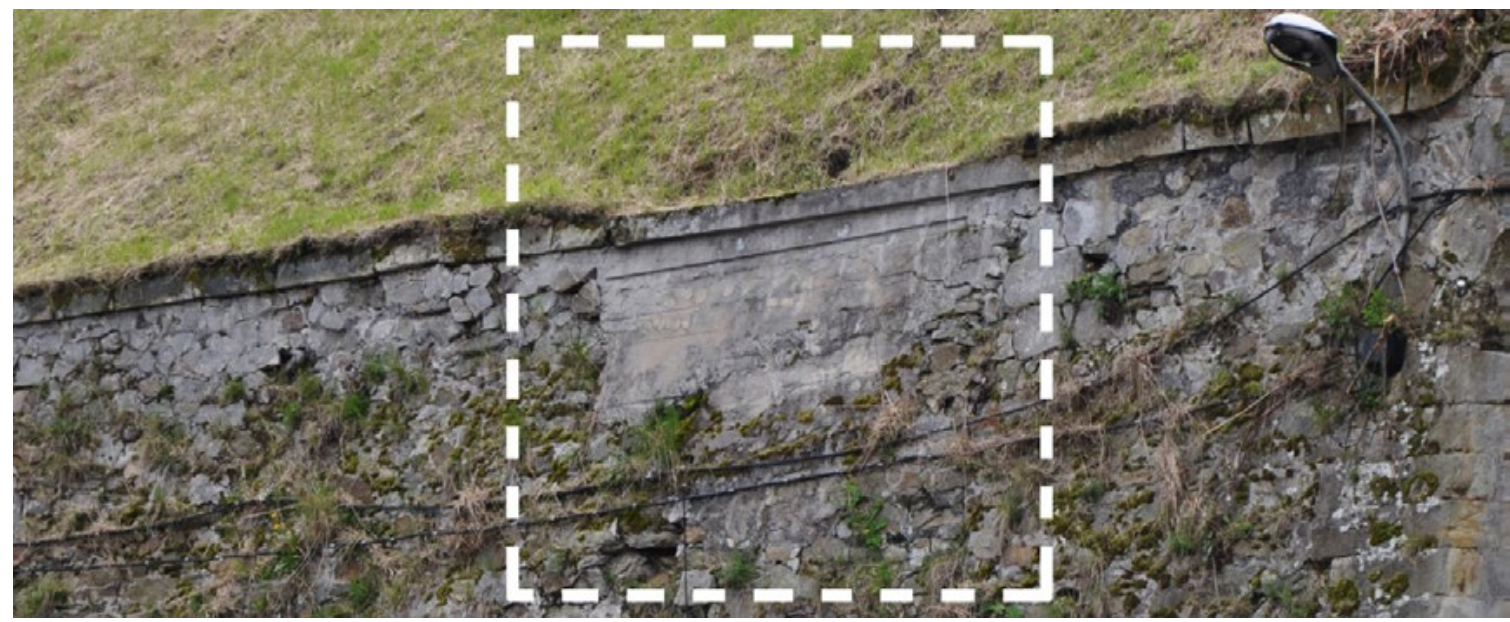

Fig. 4. Photograph showing secondary concrete filling of the face of the wall (2017) - authors' own photograph 


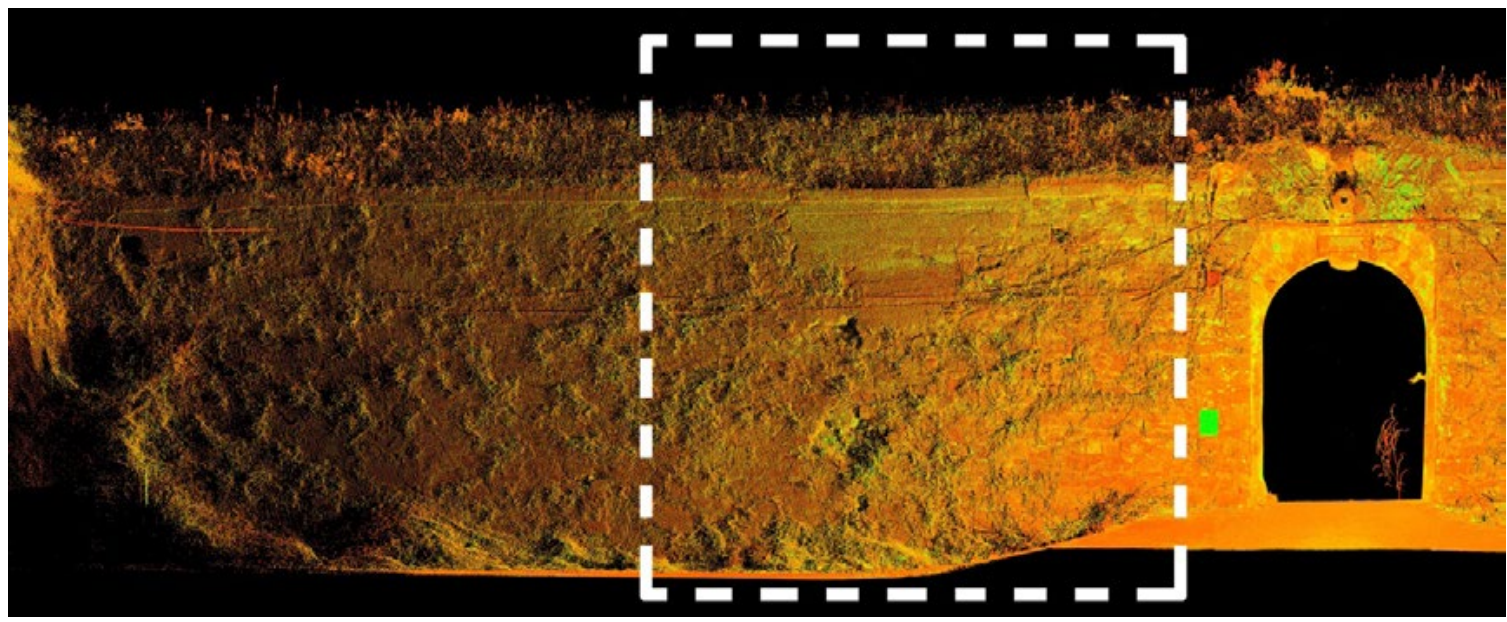

Fig. 5. Scan of the face of the wall with a marked place of the slide (2017) - authors' own elaboration

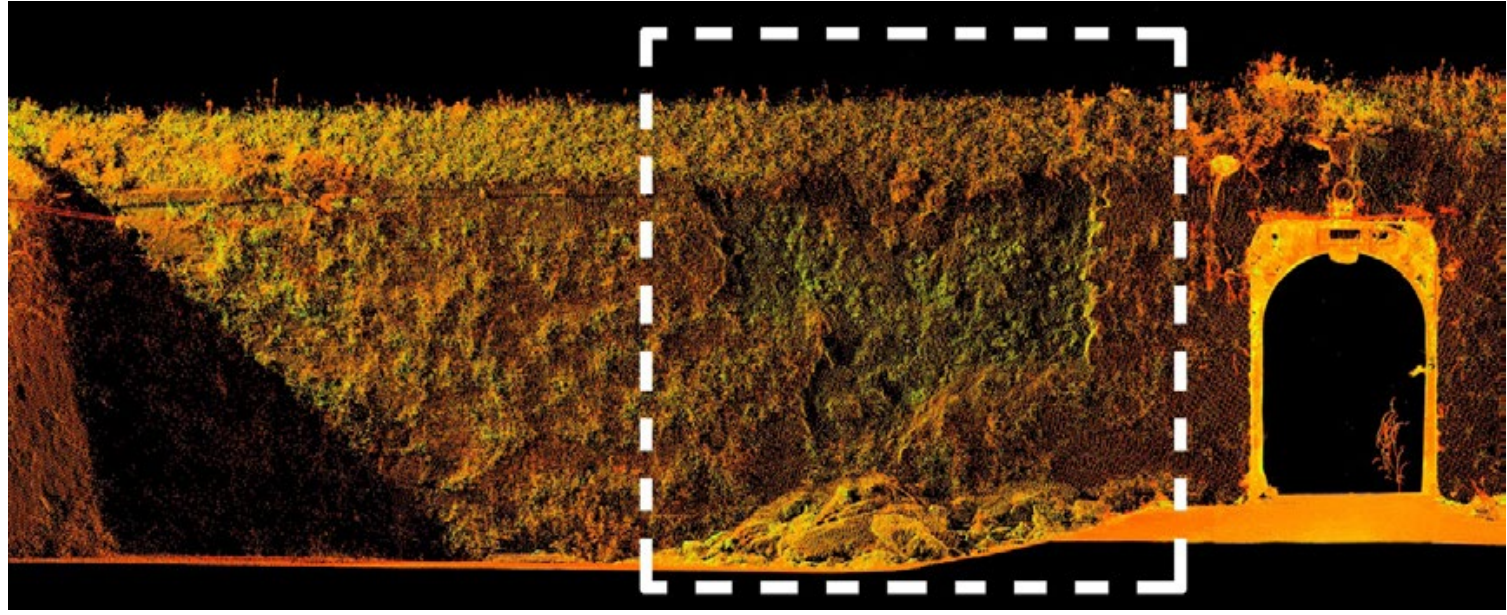

Fig. 6. Scan of the face of the wall with a marked place of the slide (2018) - authors' own elaboration

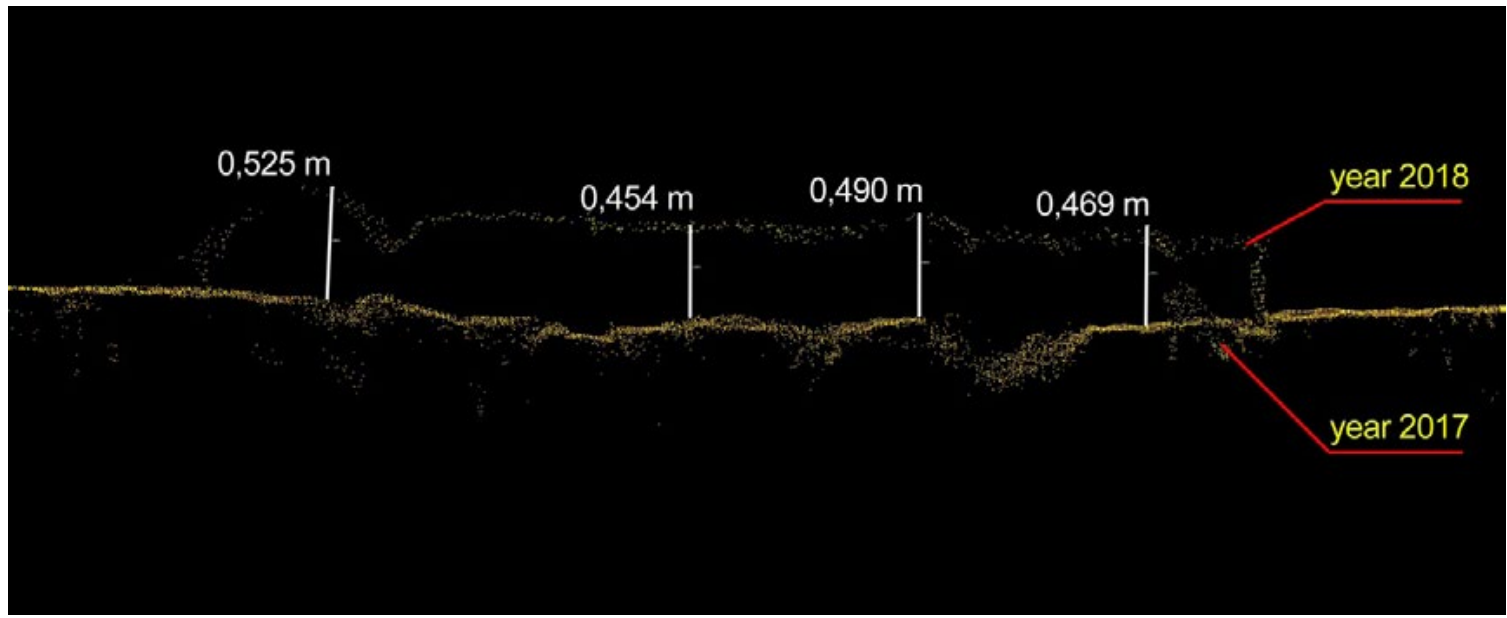

Fig. 7. Plan of walls from 2017 (before the wall slided) and 2018 (after the wall slided) - authors' own elaboration 
The table below shows a list of damages occurring in the structure of the northern face of the Great Tenaille wall. The authors describe the cause of the phenomenon and the far-reaching consequences of lack of protection and further corrosion of the wall.

Table 1. Description of observed phenomena occurring in the masonry - authors' own elaboration

\begin{tabular}{|c|c|c|c|}
\hline & Description & Reason & Results \\
\hline 1 & $\begin{array}{l}\text { local damage and } \\
\text { cavities in the face of } \\
\text { the wall }\end{array}$ & $\begin{array}{l}\text { high humidity, occurrence } \\
\text { of lichens, moss and } \\
\text { grass on the surface, poor } \\
\text { condition of the mortar, lack } \\
\text { of ongoing maintenance, } \\
\text { faulty drainage system }\end{array}$ & $\begin{array}{l}\text { deep weakening and flushing out of the } \\
\text { welds, favouring weakening of the face } \\
\text { layer of the wall and, as a consequence, } \\
\text { loosening and falling out of the building } \\
\text { material, creates good conditions } \\
\text { for seed setting and development of } \\
\text { shrubs and trees and, as a consequence, } \\
\text { weakening of the deep structure of the } \\
\text { wall, weakening of the construction of } \\
\text { the wall }\end{array}$ \\
\hline 2 & $\begin{array}{l}\text { flushing out of the } \\
\text { mortar on the surface }\end{array}$ & $\begin{array}{l}\text { high humidity, occurrence } \\
\text { of lichens, moss and } \\
\text { grass on the surface, poor } \\
\text { condition of the mortar, lack } \\
\text { of ongoing maintenance, } \\
\text { lack of waterproofing of the } \\
\text { coping }\end{array}$ & $\begin{array}{l}\text { deep weakening and flushing out of the } \\
\text { welds, favouring weakening of the face } \\
\text { layer of the wall and, as a consequence, } \\
\text { loosening and falling out of the building } \\
\text { material, creates good conditions } \\
\text { for seed setting and development of } \\
\text { shrubs and trees and, as a consequence, } \\
\text { weakening of the deep structure of the } \\
\text { wall, weakening of the construction of } \\
\text { the wall }\end{array}$ \\
\hline 3 & $\begin{array}{l}\text { point cavities and } \\
\text { damage to the coping }\end{array}$ & $\begin{array}{l}\text { occurrence of shrubs and } \\
\text { trees on or along the } \\
\text { coping, poor condition of } \\
\text { the mortar, lack of ongoing } \\
\text { maintenance, lack of } \\
\text { waterproofing of the coping }\end{array}$ & $\begin{array}{l}\text { weakening of the construction of the } \\
\text { wall creates good conditions for seed } \\
\text { setting and development of shrubs and } \\
\text { trees and, as a consequence, weakening } \\
\text { of the deep structure of the wall under } \\
\text { the damaged part of the coping }\end{array}$ \\
\hline 4 & $\begin{array}{l}\text { occurrence of shrubs } \\
\text { and trees on the slopes } \\
\text { and coping of slopes }\end{array}$ & $\begin{array}{l}\text { high humidity, occurrence } \\
\text { of lichens, moss and } \\
\text { grass on the surface, local } \\
\text { occurrence of shrubs and } \\
\text { trees on the slopes and } \\
\text { copings of escarps, lack of } \\
\text { ongoing maintenance }\end{array}$ & $\begin{array}{l}\text { deep weakening of the structure of } \\
\text { the wall causing penetration of water } \\
\text { and, as a consequence, loosening and } \\
\text { falling out of the construction material, } \\
\text { blowing up the deep structure of the } \\
\text { wall }\end{array}$ \\
\hline 5 & $\begin{array}{l}\text { deep cavities in the } \\
\text { slope construction layer } \\
\text { with landslides }\end{array}$ & \multirow{3}{*}{$\begin{array}{l}\text { high humidity and } \\
\text { salinisation, occurrence of } \\
\text { trees and shrubs on slopes } \\
\text { and slope copings, lack } \\
\text { of ongoing maintenance, } \\
\text { mechanical damage e.g. due } \\
\text { to explosion }\end{array}$} & \multirow{3}{*}{$\begin{array}{l}\text { weakening of the wall structure, the } \\
\text { building falling into ruin }\end{array}$} \\
\hline 6 & $\begin{array}{l}\text { surface damage and } \\
\text { cavities in the face of } \\
\text { the wall }\end{array}$ & & \\
\hline 7 & bursts and crevices & & \\
\hline
\end{tabular}




\begin{tabular}{|c|c|c|c|}
\hline 8 & $\begin{array}{l}\text { linear damage to the } \\
\text { wall }\end{array}$ & $\begin{array}{l}\text { occurrence of shrubs and } \\
\text { trees on or along the crown } \\
\text { of the wall, poor condition } \\
\text { of the mortar, lack of } \\
\text { ongoing maintenance, lack } \\
\text { of waterproofing of the } \\
\text { coping }\end{array}$ & $\begin{array}{l}\text { weakening of the structure of the } \\
\text { wall creates favourable conditions for } \\
\text { seeds setting and for the development } \\
\text { of shrubs and trees, and as a further } \\
\text { consequence weakening of the deep } \\
\text { structure of the wall below the damaged } \\
\text { part of the coping, the building falling } \\
\text { into ruin }\end{array}$ \\
\hline 9 & $\begin{array}{l}\text { occurrence of lichens, } \\
\text { moss and grass on the } \\
\text { surface }\end{array}$ & $\begin{array}{l}\text { high humidity, shading, no } \\
\text { ongoing maintenance }\end{array}$ & $\begin{array}{l}\text { retention of humidity in the wall, } \\
\text { superficial damage to brick and stone, } \\
\text { weakening and washing out of welds } \\
\text { creates favourable conditions for seed } \\
\text { setting and the development of shrubs } \\
\text { and trees and, as a further consequence, } \\
\text { weakens the deep structure of the wall }\end{array}$ \\
\hline
\end{tabular}

During the research work, a graphic survey of the northern face of the Great Tenaille wall was made in 2018 (Fig. 8). In the drawing presented below, the face of the wall is marked with numerous loss of material, welds, biological corrosion, demolition, contamination, greenery, displacement of construction material and landslides. The condition of the wall was then assessed as critical. Thanks to this study it is possible to make a detailed estimate of repairs necessary to stop the process of degradation.

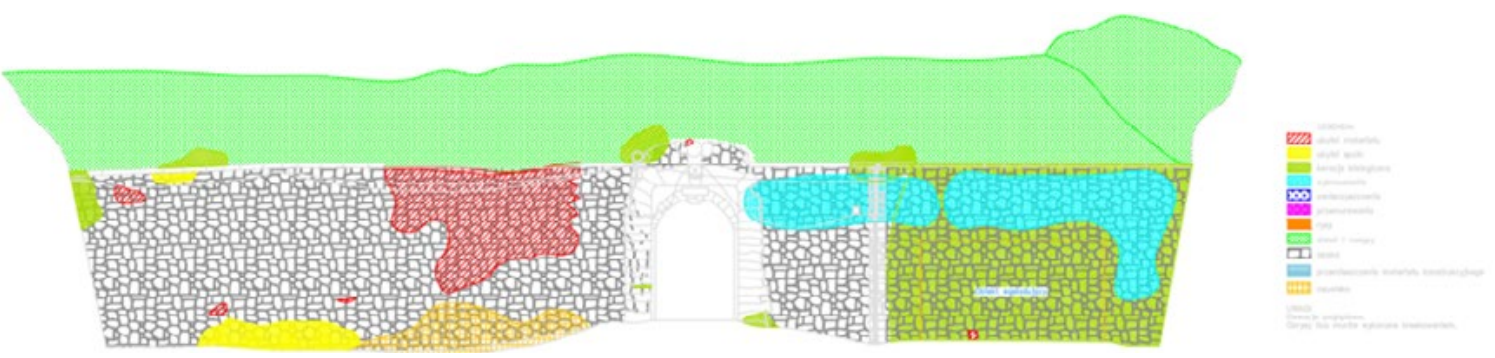

Fig. 8. Graphic survey - source: Archives of the Department of Conservation of Built Heritage, Faculty of Civil Engineering and Architecture, Lublin University of Technology

Currently, we can observe progressive degradation of the wall, further slipping of layers of stone and cornices, as well as continuous growth of invasive greenery and numerous lichens and moss (Fig. 9).

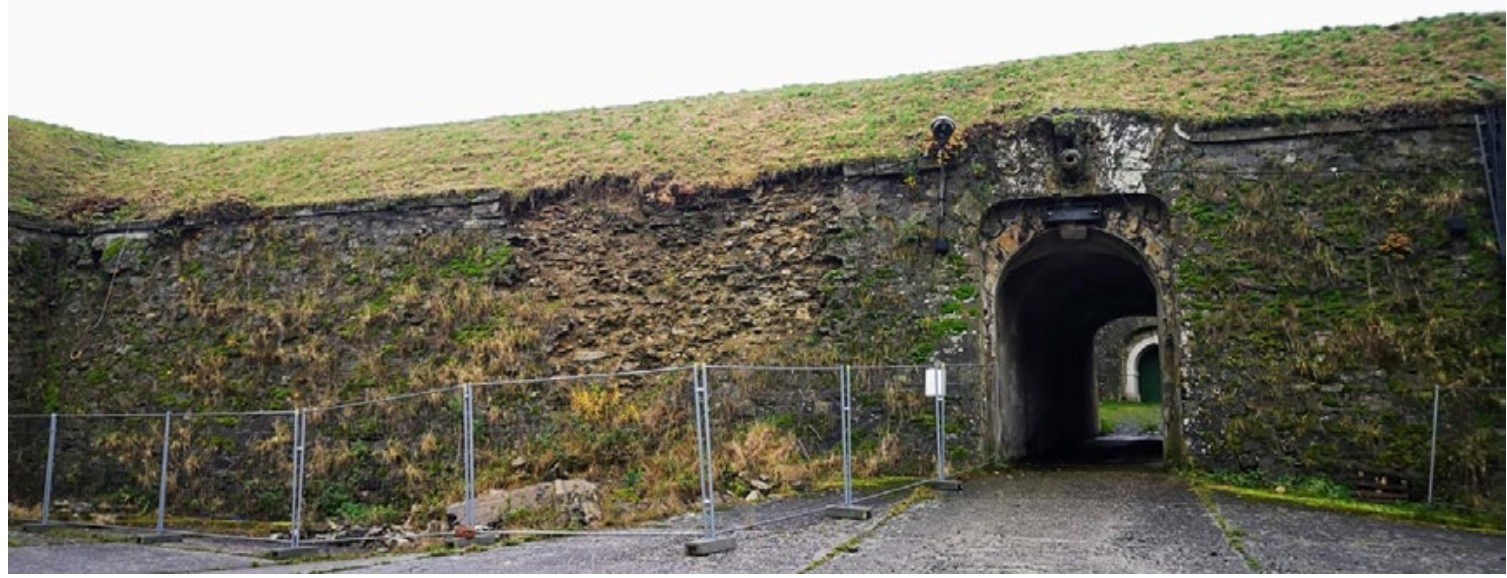

Fig. 9. Photograph showing further degradation of the wall (2020) - authors' own photograph 
In order to prevent further corrosion and to repair the existing condition of the analysed part of the wall, it is necessary to take strict conservation measures. It is essential to:

- clean the wall from degrading greenery,

- complete the welds,

replenish the cavities,

- in the case of minor cavities, protect the existing condition,

- complete the wall structure on the basis of technical expertise,

- supplement or reinforce the wall structure on the basis of technical expertise.

\section{Conclusions}

In the case of works related to historic buildings, such as fortifications, it is necessary to continue works aimed at protecting the buildings against devastation, to carry out surveying and cleaning works, to mark and describe each of the buildings of fortifications and equipment on the premises [12]. Therefore, continuous surveying works is the basis for the proper protection and maintenance of a historic monument.

This study provides an example of the possibilities offered by laser scanning in the process of survey, technical condition assessment, and architectural and conservation analysis. Thanks to the architectural research, it was possible to accurately assess the technical condition of the studied facility and to perform a comparative analysis of the process of degradation of the historic tissue. Systematic documentation of the degraded element makes it possible to assess the degradation progress and then formulate recommendations for further works related to securing the endangered structure of the wall.

These are necessary actions to ensure the durability of the historic substance. As far as the protection of cultural assets is concerned, the architectural survey together with detailed technical expertise is the basis for further actions taken by administrative authorities taking into account conservation recommendations.

\section{Literature}

[1] Gleń P., Krupa K., Comparative analysis of the inventory process using manual measurements and laser scanning, Budownictwo i Architektura 18(2) (2019)21-30 DOI: 10.35784/bud-arch.552.

[2] Rzonca A., Współczesne metody kompleksowej inwentaryzacji zabytków na przykładzie kościoła w Michalicach, w: Archiwum Fotorgametrii, Kartografii i Teledetekcji, Vol. 14, 2004.

[3] Małachowicz E., Nowożytne fortyfikacje Śląska europejskim dziedzictwem kultury.

[4] Jędrysiak T., Mikos von Rohrscheidt A., Militarna turystyka kulturowa, PWE, 2011.

[5] https://www.dawnekłodzko.pl, accessed: 09.06.2020.

[6] Decision KL-V-1/61/30 of $13^{\text {th }}$ May 1960 about the entry to the Register of the Historic Monuments.

[7] Małachowicz M., Twierdze Śląskie - 20 lat później, Fortyfikacje nowożytne w Polsce - badania, realizacje, projekty. Zagospodarowanie do wspótczesnych funkcji.

[8] Mitka B., Usability of terrestrial laser scanners for the process of documentation and modeling of historical objects, in: Archiwum Fotogrametrii, Kartografii i Teledetekcji, Vol. 17b, 2007.

[9] Remondino F., Heritage Recording and 3D Modeling with Photogrammetry and 3D Scanning, in: Remote Sensing 2011.

[10] 3D Laser Scanning of Heritage in: Historic England.

[11] Gleń P., Krupa K., The use of secondary build-up in historical fabric based on the donjon of Kłodzko Fortress in: E3S Web of Conferences, 2018, vol. 49, DOI: https://doi.org/10.1051/e3sconf/20184900031.

[12] Mikos v Rohrscheidt A., Turystyka Kulturowa, http://turystykakulturowa.org/, No. 2/2009. 